\title{
A New Approach to Rebates After Intel Case
}

\section{SANDRA FIŠER ŠOBOT}

\begin{abstract}
Although heated debates are quite common in the law on abuses of dominant position, it is not an exaggeration to state that Intel case has generated an unusual storm of comments and discussions. In 2009, the European Commission fined Intel 1.06 billion $€$ for abusing dominant position by granting exclusivity rebates. In 2014, the General Court rendered judgment in support of the European Commission`s decision. In 2017, the Court of Justice of the European Union set aside that judgment and referred the case back to the General Court in order for it to examine Intel's arguments regarding the capacity of the rebates at issue to restrict competition. This long awaited ruling in the Intel case is so far one of the most important judgments regarding exclusivity rebates and Art. 102 TFEU enforcement. The paper addresses relevant issues and conclusions in relation to the exclusivity rebates. Additionally, the author attempts to assess possible effects and implications of the Courts of Justice's judgment.
\end{abstract}

Keywords: - Art. 102 TFEU • abuse of dominant position • exclusivity rebates $\bullet$ the /as efficient competitor « test $\bullet$ effects-based approach $\bullet$

CorResPONDENCE AdDRESS: Sandra Fišer Šobot, PhD, Associate Professor, University of Novi Sad, Faculty of Law, Trg Dositeja Obradovića 1, 21000 Novi Sad, Serbia, e-mail: sfiser@pf.uns.ac.rs. 


\section{Introduction}

On 6 September 2017 the Court of Justice of the European Union (hereinafter: the CJEU) rendered its judgment in the Intel case (hereinafter: CJEU Judgment), one of the most important judgments in the field of competition law in many years. The case has been referred back to the General Court (hereinafter: the GC) in order for it to examine Intel's arguments regarding the capacity of the rebates at issue to restrict competition. This paper addresses relevant issues in relation to rebates. Additionally, the author attempts to assess possible future effects and implications of the CJEU judgment.

\section{The facts of the case and the decision of the Commission}

On 13 May 2009 the Commission issued a decision relating to a proceeding under Article 82 of the EC Treaty and Article 54 of the EEA Agreement (hereinafter: the Decision) ${ }^{1}$. Advanced Micro Devices, Inc. (hereinafter: AMD) is a company incorporated in the USA and is a global semiconductor company with facilities around the world. AMD provides processing solutions for the computing, graphics and consumer electronics markets. ${ }^{2}$ AMD submitted to the Commission a formal complaint against US company Intel Corporation (hereinafter: Intel), the world «s largest semiconductor chip maker. Namely, Intel produces chips, boards and other semiconductor components that are used in making computers, servers and networking and communications products. ${ }^{3}$ For more than 10 years Intel had a market share consistently around or above $80 \%$ of the wider market and around or above $70 \%$ in any of the desktop, laptop and server market segments (Faull, Nikpay, 2014: 438; see Fox, Gerard, 2017: 201). AMD was the only serious competitor of Intel with a market share around or above $15 \%$.

After almost a decade long proceeding, the Commission adopted the Decision and established that Intel had abused its dominant position by engaging in a single and continuous infringement of Article 82 of the Treaty [now Art. 102 TFEU] in the period from October 2002 until December 2007 by implementing a strategy aimed at foreclosing competitors from the $\mathrm{x} 86 \mathrm{CPU}$ market. The Commission fined Intel 1.060.000.000 EUR, ${ }^{4}$ which was at the time, the largest fine ever imposed by a competition regulator on an individual company. In addition, the Commission ordered Intel to immediately cease the infringement in so far as it had not already done so. ${ }^{5}$

The Decision deals with the selling of Central Processing Units (hereinafter: CPU) of the $\mathrm{x} 86$ architecture. CPU is usually referred to as a computer`s »brain«, as it is a key component of every computer, both in terms of overall performance and cost of the system. ${ }^{6}$ There are two major types of CPUs used in computers - CPUs of the

\footnotetext{
${ }^{1}$ Case COMP/C-3/37.990 — Intel, Brussels, 13.5.2009., D (2009) 3726final.

${ }^{2}$ Ibid., para. 3.

${ }^{3}$ Ibid., para. 1 .

${ }^{4}$ Ibid., para. 1803.

${ }^{5}$ Ibid., Article 3.

${ }^{6}$ See Summary of Commission Decision of 13 May 2009 relating to a proceeding under Article 82 of the
} 
x86 architecture and CPUs of a non-x86 architecture. The x86 architecture is a standard designed by Intel for its CPUs and it can operate both Windows and Linux operating systems. It is important to note that since 2000, Intel and AMD were essentially the only two companies still manufacturing x86 CPUs. ${ }^{7}$

The Decision describes two types of Intel's conduct that constituted infringement of Article 102 TFEU - conditional rebates and so-called »naked restrictions «. The first type of conduct consisted in the grant of rebates to four Original Equipment Manufacturers (hereinafter: OEMs), namely Dell, HP, NEC and Lenovo, which were conditioned on these OEMs purchasing all or almost all of their supply needs from Intel. ${ }^{8}$ The second type of conduct, naked restrictions, consisted of Intel making payments to OEMs so that they would delay, cancel or restrict the marketing of certain products equipped with AMD CPUs. ${ }^{9}$ In the similar manner, Intel awarded payments to Media Saturn Holding (hereinafter: MSH), Europe`s largest PC retailer, in return for $\mathrm{MSH}$ selling exclusively Intel-based PCs. In their effect, these payments were equivalent to the conditional rebates to OEMs. ${ }^{10}$

In the Decision, the Commission used criteria established in the case law of EU courts. It explicitly restated ${ }^{11}$ positions expressed in Hoffmann-La Roche $v$ Commission (hereinafter: Hoffmann-La Roche). ${ }^{12}$ In Hoffmann-La Roche, the CJEU established that an undertaking which is in a dominant position on a market and ties purchasers - even if it does so at their request - by an obligation or promise on their part to obtain all or most of their requirements exclusively from the said undertaking abuses its dominant position within the meaning of article $82 \mathrm{EC}$ [now Art. 102 TFEU], whether the obligation in question is stipulated without further qualification or whether it is undertaken in consideration of the grant of a rebate. The same applies if the said undertaking, without tying the purchasers by a formal obligation, applies, either under the terms of agreements concluded with these purchasers or unilaterally, a system of fidelity rebates, that is to say discounts conditional on the customer's obtaining all or most of its requirements - whether the quantity of its purchases be large or small - from the undertaking in a dominant position $\ll .{ }^{13}$ Furthermore, the granting of fidelity discounts $»$ in order to give the buyer an incentive to obtain its supplies exclusively from the undertaking in a dominant position was incompatible with the objective of undistorted competition within the common market $\ll .{ }^{14}$ The Commission concluded that the rebates granted by Intel represent fidelity rebates in the sense of Hoffmann-La Roche and that they are abusive unless objectively justified. In addition, it was established that payments made to MSH produce equivalent effect as rebates granted to OEMs and that, therefore, they also meet Hoffmann-La Roche conditions.

EC Treaty and Article 54 of the EEA Agreement (Case COMP/C-3/37.990 — Intel) (hereinafter: Summary of the Decision), OJ 2009 C-227/13-17, para. 14.

${ }^{7}$ See Summary of the Decision, para. 15.

${ }^{8}$ Summary of the Decision, para. 22.

${ }^{9}$ Case C-413/14P, Intel v Commission, ECLI:EU:C:2017:632, para. 11.

${ }^{10}$ Summary of the Decision, para. 23.

${ }^{11}$ See case COMP/C-3/37.990 - Intel, para. 920.

${ }^{12}$ Case C-85/76, Hoffmann-La Roche v Commission ECLI:EU:C:1979:36.

${ }^{13}$ Ibid., para. 89.

${ }^{14}$ Ibid., para. 90. 
After demonstrating that the conditions accepted in case law were satisfied, the Commission nonetheless examined whether the rebates were capable or likely to cause anticompetitive foreclosure. For that purpose the Commission applied the socalled as efficient competitor test (hereinafter: the AEC test) i.e. it analysed at what price a competitor which is as efficient as Intel would have to offer CPUs in order to compensate an OEM for the loss of any Intel rebate. ${ }^{15}$ The AEC test represented a hypothetical exercise and was independent of whether or not AMD was actually able to enter the market. The Commission emphasized that the Guidance on the Commission's enforcement priorities in applying Article 82 of the Treaty to abusive exclusionary conduct by dominant undertakings ${ }^{16}$ (hereinafter: the Guidance on Article 102 TFEU) was not applicable in the case at hand. ${ }^{17}$ However, it is obvious that its analysis is in line with the orientations set out in the Guidance on Article 102 TFEU. The analysis took into consideration three factors: the contestable share (the amount of the customer's purchase requirements that can realistically be switched to a new competitor in any given period); the relevant time horizon (at most one year); and, the relevant measure of viable cost (average avoidable costs). ${ }^{18}$ The analysis of the effects was conducted for prioritization purposes, not as a legal requirement (Ibanez Colomo, 2018b: 5). The Commission`s reasoning on this point was elaborated upon in more than 150 pages which represented almost $1 / 3$ of the Decision.

On the basis of the economic analysis, the Commission concluded that an »as efficient competitor « would have had to offer its x86 CPUs to the major OEMs at a price which was below its average avoidable $\operatorname{costs}^{19}$ to match Intel's conditional offers. In the case of MSH, the "as efficient competitor" would have had to offer compensation payments to match Intel's conditions which would have resulted in a net price below its AAC. That level of pricing was not viable by any economic benchmark. ${ }^{20}$ Intel's payments were considered abusive due to the fact that they were capable of having, or at least likely to have, anticompetitive foreclosure effects »since even an as efficient competitor would be prevented from supplying the OEM`s x86 CPU requirements or ensuring that MSH sells PCs based on its x86 CPUs $\ll{ }^{21}$ Finally, the Commission concluded that due to Intel's conduct, the choice of consumers was reduced and incentives to innovate were diminished. Namely, the rebates artificially restricted the choice of end-users and were detrimental to consumers in both the short and long term (see Faull, Nikpay, 2014: 438), i.e. Intel's conditional rebates and payments harmed both competition on the market and consumers. $^{22}$

It should be noted that the Commission applied both the »form based« and »effects

\footnotetext{
${ }^{15}$ See case COMP/C-3/37.990 - Intel, para. 1154.

${ }^{16}$ OJ C 45, 24. 2. 2009, p. 7-20.

${ }^{17}$ See case COMP/C-3/37.990 - Intel, para. 916.

${ }^{18}$ See Summary of the Decision, para. 30.

${ }^{19}$ Average avoidable cost is the average of the costs that could have been avoided if the company had not produced discrete amount of (extra) output, in this case the amount allegedly the subject of abusive conduct. Guidance on Art. 102 TFEU, p. 11, fn. 2.

${ }^{20}$ See case COMP/C-3/37.990 — Intel, para. 1574

${ }^{21}$ Ibid., para. 1575.

${ }^{22}$ Ibid., paras. 1597-1616.
} 
based « approaches. In the first part of the analysis, the Commission established that rebates granted by Intel were abusive in the sense of Hoffmann-La Roche and then it continued with applying the analytical methods adopted in the Guidance on Article 102 TFEU, especially the equally efficient competitor test. ${ }^{23}$ Although under previous case law it was not required to demonstrate the proof of competitive harm, the Commission actually analysed the effects of the granted rebates.

\section{The judgment of the General Court}

Intel challenged the Commission`s decision before the GC seeking its annulment or, at least, a substantial reduction of the fine. The GC, in its highly controversial judgment of 12 June 2014 (hereinafter: GC Judgment), dismissed Intel`s action for annulment in its entirety and upheld the fine. ${ }^{24}$ However, the arguments of the GC were quite different than those of the Commission.

Intel pointed out that conditional rebates are not always unlawful and that naked restrictions constitute a new category of abuse. ${ }^{25}$ Further, it submitted that the Commission failed to establish the existence of a strategy to foreclose AMD. In other words, Intel argued both that the AEC test was not applied in the correct manner and that the Commission failed to establish the capability of rebates to foreclose as efficient competitors.

The GC invoked existing case law and ascertained that in order to evaluate whether the grant of a rebate by an undertaking in a dominant position can be characterized as abusive, a distinction should be drawn between three categories of rebates. ${ }^{26}$ Quantity rebates belong to the first category. The GC reiterated the stance taken in Michelin $v$ Commission (Michelin II) that »quantity rebate systems (»quantity rebates «) linked solely to the volume of purchases made from an undertaking occupying a dominant position are generally considered not to have the foreclosure effect prohibited by Article 102 TFEU. If increasing the quantity supplied results in lower costs for the supplier, the latter is entitled to pass on that reduction to the customer in the form of a more favorable tariff. Quantity rebates are therefore deemed to reflect gains in efficiency and economies of scale made by the undertaking in a dominant position $\ll .{ }^{27}$ The second type of rebates is usually referred to either as fidelity, ${ }^{28}$ exclusivity ${ }^{29}$ or loyalty rebates. ${ }^{30}$ The GC used the term exclusivity, while the CJEU used the term loyalty rebates. In this paper, the terms exclusivity and loyalty rebates will be used interchangeably. The grant of such rebates is conditional on the customer's obtaining all or most of its requirements from the undertaking in a dominant position. Exclusivity rebates are considered incompatible with the objective of undistorted competition on the market, because

\footnotetext{
${ }^{23}$ See case COMP/C 3/37.990 — Intel, para. 1154.

${ }^{24}$ Case T-286/09. Intel v Commission, ECLI:EU:T:2014:547.

${ }^{25}$ Ibid., para. 1599.

${ }^{26}$ Ibid., para. 74.

${ }^{27}$ Case T-203/01, Michelin v Commission, ECLI:EU:T:2003:250, para. 58; case T-286/09, Intel v Commission ECLI:EU:T:2014:547, para. 75.

${ }^{28}$ Case 85/76, Hoffmann-La Roche v Commission, ECLI:EU:C:1979:36, para. 90.

${ }^{29}$ Case T-286/09, Intel Corporation v Commission, ECLI:EU:T:2014:547, para.76.

${ }^{30}$ Case C-413/14P, Intel v Commission, ECLI:EU:C:2017:632.
} 
they are designed to remove or limit »the purchaser`s freedom to choose his sources of supply and to deny other producers access to the market «. ${ }^{31}$ Those rebates will be prohibited unless the respective conduct can be objectively justified (see Jones, Sufrin, 2016: 365; Ibanez Colomo, 2018a: 197). Finally, other rebate systems where the mechanism for granting the rebate may also have a fidelity-building effect belong to the third category of rebates. ${ }^{32}$ Those rebates are not associated with a condition of exclusive or quasi-exclusive supply from the dominant firm. However, they represent financial incentives that can sometimes be considered abusive. They are not per se illegal but it is necessary to consider all the circumstances, "particularly the criteria and rules governing the grant of the rebate, and to investigate whether, in providing an advantage not based on any economic service justifying it, that rebate tends to remove or restrict the buyer`s freedom to choose his sources of supply, to bar competitors from access to the market, or to strengthen the dominant position by distorting competition $« .{ }^{33}$ The third type of rebates are scrutinized in light of all of the circumstances (see Petit, 2018: 5). This classification was largely endorsed by the CJEU in Post Danmark II. ${ }^{34}$

The GC found that the rebates granted to the OEMs fall within the second category i.e. that they constitute exclusivity rebates. ${ }^{35}$ Furthermore, the GC stated that the abusive nature of exclusivity rebates »does not depend on an analysis of the circumstances of the case aimed at establishing a potential foreclosure effect $\ll{ }^{36}$ In other words, when exclusivity rebates are granted it is not necessary to asses all of the circumstances of the case in order to analyze their effects on the competition on the market. Instead, those rebates should be deemed to represent the abuse of dominance in the sense of Art. 102 TFEU (abuse »by object«), because by their very nature they are capable of restricting competition ${ }^{37}$ and of foreclosing competition. ${ }^{38}$ In this respect, the GC disregarded the relevant case law on Article 101(1) TFEU (in particular Delimitis ${ }^{39}$ ), $\gg$ which is based on the premise that exclusive dealing is not restrictive by object and has a pro-competitive justification« (Ibanez Colomo, 2018b: 6). Also, the GC failed to acknowledge that not all restrictions by object are created equally.

The GC Judgment did not impose a per se prohibition of rebates, since the GC held that exclusivity rebates are always prohibited unless there is objective justification for such conduct. ${ }^{40}$ However, the established rule is very strict and it is expected that the process of proving that exclusivity rebates were objectively justified would be »a very difficult hurdle to overcome« (Whish, Bailey, 2015: 773). In theory, this is

\footnotetext{
${ }^{31}$ Case T-286/09, Intel Corporation v Commission, ECLI:EU:T:2014:547, para. 77. See also, case 85/76, Hoffmann-La Roche v Commission, ECLI:EU:C:1979:36, para. 90 and T-155/06, Tomra Systems and Others v Commission, ECLI:EU:T:2010:370, para. 209.

${ }^{32}$ Case T-286/09, Intel Corporation v Commission, ECLI:EU:T:2014:547, para.78.

${ }^{33}$ Ibid., paras.78, 82.

${ }^{34}$ Case C-23/14, Post Danmark A/S v Konkurrencerådet, ECLI:EU:C:2015:651, paras. 27-29.

${ }^{35}$ Case T-286/09, Intel Corporation v Commission, ECLI:EU:T:2014:547, para.79.

${ }^{36}$ Ibid., para. 80 .

${ }^{37}$ Ibid., para. 85 .

${ }^{38}$ Ibid., para. 87.

${ }^{39}$ Case C-234/89, Stergios Delimitis v Henninger Bräu, AG, ECLI:EU:C:1991:91.

${ }^{40}$ Case T-286/09, Intel Corporation v Commission, ECLI:EU:T:2014:547, para. 81.
} 
referred to as a quasi per se prohibition rule (Petit, 2018: 4; Jones Sufrin, 2016: 365).

The GC restated the rule from Hoffman-La Roche ${ }^{41}$ that as regards abuses of dominant position there is no appreciability or de minimis threshold. It held that the possible sparsity of the parts of the market which are concerned by the practices at issue is not a relevant consideration. The main argument supporting this reasoning is that the mere existence of a dominant undertaking on the relevant market changes the structure of the competition and, therefore, any further weakening of the structure of competition may constitute an abuse of a dominant position. ${ }^{42}$

Intel argued that the Commission had been required both to carry out an analysis of the circumstances of the case in order to establish at least a potential foreclosure effect $^{43}$ and to establish the existence of actual foreclosure effects. ${ }^{44}$ In its application for annulment, Intel emphasized that the AEC test was an important factor for establishing the potential foreclosure effects of the granted rebates. Its relevance stems from the fact that the Commission proved that the rebates were capable of restricting competition on the basis of the AEC test. ${ }^{45}$ The GC rejected all of Intel's arguments regarding the relevance of the test and the errors in the application of that test by the Commission. The stance advocated in the GC Judgment was in line with the position that the exclusivity rebates are forbidden unless objectively justified and that, therefore, it is not mandatory either to prove their actual or potential foreclosure effects or to use the AEC test. The GC stated that »even in the case of rebates falling within the third category, for which an examination of the circumstances of the case is necessary, it is not essential to carry out an AEC test ${ }^{46}$

The GC Judgment explicitly affirmed that the Commission only need show that the practice is capable of restricting competition, and not that the practice constitutes an actual detriment to competition. ${ }^{47}$ In the case of exclusivity rebates, in order to establish a potential anti-competitive effect, it is sufficient to demonstrate the existence of a loyalty mechanism. ${ }^{48}$

The GC Judgment emphasized that even if the analysis of the circumstances of the case is needed, it is not essential to employ the AEC test in order to establish potential anti-competitive effects of the exclusivity rebates (in theory see Ezrachi, 2016: 259). ${ }^{49}$ The GC further said that »an AEC test only makes it possible to verify the hypothesis that access to the market has been made impossible and not to rule out the possibility that it has been made more difficult $\ll{ }^{50}$ It additionally explained that from a negative result of the AEC test the conclusion can be reached »that it is

\footnotetext{
${ }^{41}$ Case 85/76, Hoffmann-La Roche v Commission ECLI:EU:C:1979:36, para. 123.

${ }^{42}$ Case T-286/09, Intel Corporation v Commission, ECLI:EU:T:2014:547, para. 116.

${ }^{43}$ Ibid., paras. 95-101.

${ }^{44}$ Case T-286/09, Intel Corporation v Commission, ECLI:EU:T:2014:547, paras 102-105.

${ }^{45}$ Ibid., para. 140.

${ }^{46}$ Ibid., para. 144.

${ }^{47}$ Ibid., paras 103, 177.

${ }^{48}$ Ibid., para. 145; case C-549/10 P, Tomra and Others v Commission, ECLI:EU:C:2012:221, para. 79.

${ }^{49}$ See case T-286/09, Intel Corporation v Commission, ECLI:EU:T:2014:547, paras. 144, 146.

${ }^{50}$ Ibid., para. 150.
} 
economically impossible for an as-efficient competitor to secure the contestable share of a customer's demand. In order to offer a customer compensation for the loss of the exclusivity rebate, that competitor would be forced to sell its products at a price which would not allow it even to cover its costs. However, a positive result means only that an as-efficient competitor is able to cover its costs « ${ }^{51}$ The positive result does not as such imply that there is no foreclosure effect.

The GC concluded that the Commission demonstrated the requisite legal standard and that according to an analysis of the circumstances of the case the exclusivity rebates and payments granted by Intel to the OEMs were capable of restricting competition. ${ }^{52}$ According to the GC's view, the AEC test was not the only evidence presented in the Decision which demonstrates that the exclusivity payments were capable of restricting competition. ${ }^{53}$ The following circumstances also were taken into account. First, Intel`s business strategy and its goals were important. The GC considered that rebates were part of Intel«s long-term strategy aimed at foreclosing competitors from the market and that such practices were capable of producing or likely to produce a foreclosure effect. ${ }^{54}$ Second, the fact that Intel was an unavoidable trading partner was also significant in the sense of non-contestable and contestable part of demand on the relevant market. Even if it was established that exclusivity rebates were not, in and of themselves, capable of restricting competition, the grant of financial incentives by Intel, as an unavoidable trading partner, should be considered as at least an indication of the capability of such rebates to restrict competition. The GC stated that $»$ where it is granted by an unavoidable trading partner, an exclusivity rebate enables the latter to use its economic power on the non-contestable portion of the demand as leverage to secure also the contestable share, thus making access to the market more difficult for the competitor «. ${ }^{55}$ The third factor that was presented was the attempt of the dominant undertaking to tie important customers. ${ }^{56}$ This factor was especially meaningful in the cases of both Dell and HP due to their high market shares. Finally, the GC held that the rebates should be appraised in the sense of Intel's overall strategy that was aimed at barring AMD`s access to the most important sales channels. This aspect of Intel's conduct also confirmed the capability of exclusivity rebates to restrict competition. $^{57}$

The GC rejected Intel's arguments regarding the potential beneficial effects of the rebates. It stated that in the market with the dominant undertaking competition is restricted $^{58}$ and those restrictions cannot be counterbalanced or outweighed by advantages in terms of efficiency which also benefit the consumer.

Although the formalistic approach of the GC imposed a »lower threshold « for assessing the rebates than the »more economic approach«, nevertheless it still was in

\footnotetext{
${ }^{51}$ Ibid., para. 150.

52 Ibid., para. 197.

${ }^{53}$ Ibid., para. 175 .

${ }^{54}$ Ibid. para. 173.

${ }^{55}$ Ibid., para. 178.

${ }^{56}$ Ibid., para. 182.

${ }^{57}$ Ibid., para. 184.

${ }^{58}$ SIbid., para. 189.
} 
line with the previous case law. However, the GC Judgment was heavily discussed in doctrine (see Jones, Sufrin, 2016: 440 and fn. 481; Ibanez Colomo, 2014: 3, fn. 8). Different commentators accentuated the following. First, the argument was advanced that the formalistic approach may have resulted in a general ban of rebate schemes that in reality may actually be beneficial to consumers and may »chill legitimate business behavior « (Whish, 2015: 1). Second, the GC Judgment widened the gap between what the Commission intended to achieve by its Guidance on Article 102 TFEU and the jurisprudence of the EU courts. Namely, the GC's refusal to apply the AEC test was interpreted as a rejection of the "an effects based " approach to the enforcement of Art. 102 TFEU and as an implied rejection of the Guidance on Article 102 TFEU (see more Whish, 2015: 2). Commentators also analyzed the GC«s application of the Hoffman-La Roche rule. Some authors stressed, for example, that the Hoffman-La Roche standard has to be abandoned due to the fact that exclusivity rebates and loyalty rebates do not automatically have anticompetitive effects. In addition, their purpose is not always exclusionary. Others defended the rule in Hoffman-La Roche, as being consistent with the TFEU (see Ibanez Colomo, 2018b: 7).

Some prominent authors, however, emphasized that the CJEU applied the AEC test in Post Danmark $I^{59}$ and TeliaSonera, ${ }^{60}$ the cases dealing with the pricing practices of dominant companies. The main distinction between the Intel case and those cases is that in the former the essence of the problem was the exclusivity of the rebate and not the price. Therefore, the dominant undertaking has to produce evidence to justify it (see Whish, 2015: 2). On the other hand, some commentators are of the view that "a careful reading of the judgment shows that much of the criticism is misplaced " (Whish, 2015: 2).

Also, Advocate General Mr. Wahl in its Opinion (hereinafter: AC Opinion) criticized most aspects of the GC Judgment. ${ }^{61}$ Although the AC Opinion is not binding for the CJEU it was notable for proposing to overturn the GC Judgment on all grounds except for the amount of the fine.

According to Mr. Wahl, all rebates are similar in their nature and effects and may be capable of restricting the competition. ${ }^{62}$ Therefore, Mr. Wahl held that there are neither theoretical nor practical reasons to distinguish between different categories of rebates (see Ibanez Colomo, 2018b: 7).

In addition, he especially rejected the GC«s classification of exclusivity rebates as presumptively unlawful. The AC Opinion emphasized that it is of essential importance to determine the correct legal test applicable to the exclusivity rebates ${ }^{63}$ and strongly advocated the use of an »effects based « approach to the problem.

\footnotetext{
${ }^{59}$ Case C-209/10, Post Danmark A/S v Konkurrencerådet, ECLI:EU:C:2012:172.

${ }^{60}$ Case C-52/09, Konkurrensverket v TeliaSonera Sverige AB, ECLI:EU:C:2011:83.

${ }^{61}$ Opinion of Advocate General Wahl in case C-413/14 P, Intel v Commission, ECLI:EU:C:2016:788.

${ }^{62}$ Ibid., paras 89-93.

${ }^{63}$ Ibid., para. 52.
} 
One of the key issues was whether the circumstances of each case should be analyzed when establishing the existence of the abuse of dominance. In that sense, Mr. Wahl made accurate observation by stating that "an abuse of dominance is never established in abstract: even in the case of presumptively unlawful practices, the Court has consistently examined the legal and economic context of the impugned conduct «. The conduct scrutinized must, at the very least, be able to foreclose competitors from the market in order to fall under the prohibition laid down in Article 102 TFEU. ${ }^{64}$ The AC Opinion suggested that the »context is essential« because loyalty rebates are not always harmful and in fact in some cases actually may enhance rivalry (see Fox, Gerard, 2017: 204; Petit, 2018: 6). ${ }^{65}$

\section{The judgment of the Court of Justice of the European Union}

In its appeal, Intel submitted that the GC erred in law by failing to examine the rebates at issue in the light of all the relevant circumstances. ${ }^{66}$ This argument can be divided into three parts: i) the GC failed to examine all the relevant circumstances in order to establish the abusive nature of the rebates; ii) the GC failed to assess the likelihood of a restriction of a competition; and iii) the GC«s analysis concerning the capability of the rebates to restrict competition is insufficient and inadequate.

Regarding the first argument, Intel pointed out that »loyalty rebates may be found abusive only after an examination of all the relevant circumstances in order to assess whether the rebates are capable of restricting competition $\ll{ }^{67}$ Intel added that neither the wording nor the structure of Article 102 TFEU suggests that some types of conduct, when undertaken by an undertaking in a dominant position, must be treated as inherently anticompetitive. ${ }^{68}$ It further submitted that $\gg$ the settled case law of CJEU requires an examination of all the circumstances, including the level of the rebates in question, their duration, the market shares concerned, the needs of customers and the capability of the rebates to foreclose an as efficient competitor (as efficient competitor test, »the AEC test«), in order to establish that those rebates are capable of restricting competition and, accordingly, constitute an abuse of a dominant position within the meaning of Article 102 TFEU $\ll{ }^{69}$ In other words, in order to qualify certain conduct as an abuse of dominance, this conduct should be placed in relevant legal and economic context. ${ }^{70}$ Abuse of dominance cannot be established in abstracto, but it is essential to examine relevant circumstances in each particular case.

The second line of Intel's arguments was that the GC failed to assess the likelihood of a restriction of competition. Intel submitted that the fact that the rebates were

\footnotetext{
${ }^{64}$ Ibid., para. 73 .

${ }^{65}$ Ibid., para. 78.

${ }^{66}$ Case C-413/14 P, Intel v Commission, ECLI:EU:C:2017:632, para. 31.

${ }^{67}$ Ibid., para. 109.

${ }^{68}$ Ibid., para. 110.

${ }^{69}$ Ibid., para. 111. Compare with Guidance on Art. 102 TFEU, para. 20.

${ }^{70}$ Opinion of Advocate General Wahl in case C-413/14 P, Intel v Commission, ECLI:EU:C:2016:788, para. 73.
} 
categorized as exclusivity rebates should not exclude examination of their capability to restrict competition. ${ }^{71}$

The third argument was that the GC's analysis concerning the capability of the rebates to restrict competition was insufficient and inadequate. Intel emphasized that the GC failed to consider highly relevant circumstances such as insufficient market coverage of the rebates at issue, the short duration of the practices at issue, the lack of foreclosure and rapid decline in prices. ${ }^{72}$ Finally, Intel challenged the GC «s assessment of the relevance of the AEC test applied by the Commission. It further submitted that, since the Commission applied the test, the GC should have examined Intel«s line of argument alleging that the application of that test was badly flawed and that, had it been correctly applied, it would have led to the conclusion contrary to that which the Commission reached, namely that the rebates at issue were not capable of restricting competition. ${ }^{73}$

In the judgment the CJEU did not develop an analytical framework for the assessment of rebate schemes. Instead, the Court reiterated positions established in case law, namely that the purpose of Art. 102 TFEU is to protect the competition on the market. In other words, Art. 102 TFEU should not ensure that »competitors less efficient than the undertaking with the dominant position should remain on the market $\ll .{ }^{74}$ Accordingly, not every exclusionary effect is necessarily detrimental to competition.

The CJEU further clarified that pursuant to Art. 102 TFEU the existence of a dominant position and its strengthening are not forbidden. Every undertaking, including dominant firm, can compete on the merits. However, the dominant firm has a special responsibility not to allow its behavior to impair genuine, undistorted competition on the internal market. ${ }^{75}$ Therefore, in order to strengthen its dominant position, the dominant undertaking is not allowed to adopt pricing practices that have an exclusionary effect on competitors as efficient as the dominant undertaking and to use methods other than those that are part of competition on the merits. ${ }^{76}$ In this manner, the CJEU reaffirmed a principle that a decline in the position of the competitors is not sufficient for finding an abuse. Additionally, it confirmed the relevance of the AEC test for analyzing pricing practices (Cleary Gottlieb, 2017: 3).

The CJEU cited Hoffman-La Roche and retained the presumption of illegality of rebates. However, the Court pointed out that the case law must be further clarified in the case where the undertaking concerned submits, during the administrative procedure, on the basis of supporting evidence, that its conduct was not capable of restricting competition and, in particular, of producing the alleged foreclosure

\footnotetext{
${ }^{71}$ See case C-413/14 P, Intel v Commission, ECLI:EU:C:2017:632, para. 113.

${ }^{72}$ Ibid., paras 115-119.

${ }^{73}$ Ibid., para. 132.

${ }^{74}$ Ibid., para. 133.

${ }^{75}$ Ibid., para. 135; case 322/81, Nederlandsche Banden-Industrie-Michelin v Commission, ECLI:EU:C:1983:313, para. 57; case C-209/10, Post Danmark A/S v Konkurrencerådet, ECLI:EU:C:2012:172, para. 23.

${ }^{76}$ Case C-413/14 P, Intel v Commission, ECLI:EU:C:2017:632, para. 136; case C-209/10, Post Danmark A/S v Konkurrencerådet, ECLI:EU:C:2012:172, para. 25.
} 
effects. ${ }^{77}$ In that case, the Commission is not only required to analyze, first, the extent of the undertaking`s dominant position on the relevant market and, second, the share of the market covered by the challenged practice, as well as the conditions and arrangements for granting the rebates in question, their duration and their amount; it is also required to assess the possible existence of a strategy aiming to exclude competitors that are at least as efficient as the dominant undertaking from the market. ${ }^{78}$ As we can see, the CJEU listed the elements that the Commission should consider. This checklist is not exhaustive and is in line with para. 20 of the Guidance on Article 102 TFEU.

Therefore, if the Commission analyzed all relevant circumstances, the GC would have been obliged to examine all of the Intel«s arguments »seeking to call into question the validity of the Commission«s findings concerning the foreclosure capability of the rebate concerned $\ll .{ }^{79}$ In other words, the CJEU held that in order to determine potential foreclosure effects of the rebates, the GC should have examined the Commission«s analysis and all of Intel«s arguments rebutting Commission«s findings.

The CJEU acknowledged that a system of rebates can be objectively justified, i.e. that the exclusionary effect arising from such a system, which is disadvantageous for competition, may be counterbalanced, or outweighed, by advantages in terms of efficiency which also benefit the consumer. ${ }^{80}$

As noted above, in its Decision the Commission combined both a formalistic approach with an effects-based approach. At the outset, it concluded that the rebates were, by their very nature, capable of restricting competition. Nevertheless, it carried out an in-depth examination of all the circumstances of the case, placing special emphasis on the AEC test. The conclusion arising out of the analysis was that $>$ an as efficient competitor would have had to offer prices which would not have been viable and that, accordingly, the rebate scheme at issue was capable of having foreclosure effects on such a competitor $«{ }^{81}$ Due to the fact that the AEC test played an important role in the Commission«s assessment, the CJEU took the stance that the GC was required to examine all of Intel «s arguments concerning the test. ${ }^{82} \mathrm{On}$ the contrary, the GC held that it was not necessary to consider whether the Commission had carried out the AEC test in accordance with the applicable rules and without making any errors. Further, the GC attached no importance to the AEC test and, consequently, did not address Intel«s arguments and criticism of that test.

Consequently, the CJEU set aside the judgment of the GC since, in its analysis of whether the rebates at issue were capable of restricting competition, the GC had failed to take into consideration Intel«s line of arguments seeking to expose alleged

\footnotetext{
${ }^{77}$ Case C-413/14 P, Intel v Commission, ECLI:EU:C:2017:632, para. 138, emphasis added

${ }^{78}$ Ibid., para. 139. Compare with The Guidance on Art. 102, para. 20.

${ }^{79}$ Ibid., para. 141.

${ }^{80}$ Ibid., para. 140.

${ }^{81}$ Ibid., para. 142.

${ }^{82}$ Ibid., para. 144.
} 
errors committed by the Commission in the AEC test. ${ }^{83}$ In other words, the GC did not establish whether the rebates at issue were capable of restricting competition due to its erroneous interpretation of Art. 102 TFEU.

\section{The main features of the CJEU judgment}

The implications of the CJEU Judgment are significant and, in general, may be divided into two categories. On the one hand, the case was referred back to the GC. This was a »major victory« for Intel (for more, see Giles, Modrall, 2017). The GC will have to reassess its conclusions. Eventually, the fine imposed on Intel may be considerably reduced.

On the other hand, the Judgment may have far-reaching consequences on the future application of Art. 102 TFEU, i.e. to the legal test applicable to pricing practices of dominant firms. In addition, the CJEU Judgment may play an important role in a number of Commission«s investigations of alleged abuses of the dominant position (see more Giles, Modrall, 2017).

Exclusivity rebates can be examined in two different ways. First, a strictly formalistic approach suggests that exclusivity rebates are abusive in their nature and, as such, prohibited regardless of the circumstances. This means that a certain practice is considered an abuse of the dominant position merely because it takes a certain form and not because of its effects in the specific case. These types of abuses are called »by object« abuses (Jones, Sufrin, 2016: 365 - the terminology reflects Art. 101 TFEU terminology). The major deficiency of the formalistic position is that it does not take into consideration the actual effects of rebates on competition. Second, the effects-based approach is advocated in the Commission«s Guidance on Article 102 TFEU and is consistent with recent CJEU case law regarding pricing practices under Art. 102 TFEU ${ }^{84}$ According to this concept, the conduct of the dominant undertaking should be examined in the sense of its capability to foreclose competitors from the market. This analytical model relies on the actual effects of the rebates on the competition on the relevant market. The difference between the two approaches is reflected primarily in the requirements that are considered necessary for the existence of an abuse of the dominant position. Namely, the form-based threshold for finding of abuse is lower than the »actual effect « threshold used by the Commission and advocated in the Guidance on Article 102 TFEU (see Ezrachi, 2016: 256).

The question that then arises is which concept is supported by the CJEU or, in other words, what was the CJEU«s legal interpretation of exclusivity rebates. Obviously, the CJEU did not entirely endorse the GC«s formalistic approach. This author «s opinion is that the CJEU merely clarified rather than overruled para. 89 of HoffmanLa Roche. In support of this opinion, this author observes that the CJEU explicitly invoked pre-existing case law on exclusive dealing and loyalty rebates and stated that exclusive dealings by the dominant firm are prima facie abusive under Art. 102

\footnotetext{
${ }^{83}$ Ibid., para. 147.

${ }^{84}$ Case C-209/10, Post Danmark A/S v Konkurrencerådet v Commission, ECLI:EU:C:2012:172.
} 
TFEU. ${ }^{85}$ However, the CJEU pointed out that case law must be further clarified in a situation where the undertaking concerned submits evidence that its conduct was not capable of restricting competition and, in particular, capable of producing the alleged foreclosure effects. ${ }^{86}$ Namely, the CJEU explicitly recognised that it is always possible for a dominant undertaking to demonstrate that, in the specific circumstances of the case, the rebate scheme is not capable of restricting competition and, in particular, capable of having exclusionary effects. Hence, if it appears that the practice is incapable of having anticompetitive effects, it is no longer safe to presume that the rationale for the practice is anticompetitive (Ibanez Colomo, 2018b: 13; see also Ibanez Colomo, 2018a: 198).

Although there is a presumption that exclusivity rebates are illegal, the dominant firm can rebut this presumption by submitting evidence that the conduct in issue is not capable of distorting competition. In such a case the evidential burden of proof is reversed to a dominant firm, in a way that it has to adduce evidence demonstrating objective justification. It is highly likely that every dominant undertaking will argue that its practice is not capable or likely to produce foreclosure effects. The Commission will have to assess those arguments, to analyse all the circumstances of the case and to show anticompetitive effects (see Cleary Gottlieb, 2017: 3). The analysis threshold is now significantly higher due to the fact that the future scrutiny of rebates will probably include economic analysis.

The CJEU clarified the role of the AEC test. It should be noted that the AEC analysis is essentially a framework, not a strict test. Its goal is to provide an instrument that focuses analysis on the dominant undertaking «s costs which are observable and known, unlike the costs of potential or actual competitors deprived of scale (Petit, 2018: 21). The practices of dominant undertakings are caught by Art. 102 TFEU only when they result in exclusion of equally efficient competitor from the market. However, the CJEU did not say that the application of the AEC test is mandatory for the Commission in every case. Sometimes it would be possible to establish lack of anticompetitive effects through other means (e.g. when a loyalty rebate covered a small part of the market) (see Ibanez Colomo, 2018b: 3). The AEC test is one of the tools among others for the purposes of assessing whether there is an abuse of a dominant position in the context of a rebate scheme. ${ }^{87}$ Nonetheless, if a dominant undertaking submits evidence that its conduct lacks foreclosures effects, »the Commission may have to conduct a full AEC Test in order to counter the company«s position« (Cleary Gottlieb, 2017: 3). Some authors believe that the application of the test would be too burdensome for the Commission.

One of the important deficiencies of the CJEU Judgment is that the CJEU failed to bring greater clarity to the meaning of »capability«. For the conduct of the dominant undertaking to be abusive it has to be capable of restricting competition or likely to restrict competition. Still, the notion of »capability « is not defined. Some authors emphasize that it is not quite clear whether the »capability" and »likelihood" thresholds are the same (see Cleary Gottlieb, 2017: 5) while others believe that it is

\footnotetext{
${ }^{85}$ Case C-413/14 P, Intel v Commission, ECLI:EU:C:2017:632, para. 137.

${ }^{86}$ Ibid., para. 138.

${ }^{87}$ See case C-23/14, Post Danmark A/S v Konkurrencerådet, ECLI:EU:C:2015:651, para. 61.
} 
possible to read the CJEU Judgment together with previous case law and to grasp the meaning of capability (see Ibanez Colomo, 2018b: 14). In the case law those terms have different meaning. Namely, the threshold of capability is a relatively low one and can be equated with plausibility (Ibanez Colomo, 2018b: 14; for detailed analysis of the meaning of »capability « and »likelihood « see Ibanez Colomo, 2018b: 14-20). On the contrary, in its Opinion, the AC Mr. Wahl held »that those terms designate one and the same compulsory step in an analysis seeking to determine whether the use of loyalty rebates amounts to an abuse of a dominant position « ${ }^{88}$ It further clarified that the aim of the assessment of capability is to ascertain whether, in all likelihood, the impugned conduct has an anticompetitive foreclosure effect. For that reason, the likelihood must be considerably more than a mere possibility that certain behavior may restrict competition. The fact that an exclusionary effect appears more likely than not is simply not enough. ${ }^{89} \mathrm{Mr}$. Wahl«s position was not followed in the CJEU Judgment and the CJEU missed the opportunity to establish the meaning of the term »capability«.

\section{Concluding remarks}

The CJEU Judgment reflects the latest position of the CJEU and brings greater clarity, legal certainty and legal consistency in Art. 102 TFEU enforcement. According to the author «s opinion, it will have important implications on future application of Art. 102 TFEU not only in the rebate cases, but also to the analysis of other abusive practices under Art. 102 TFEU.

Although quite terse, the CJEU Judgment introduced two important clarifications regarding the nature and the scope of Art. 102 TFEU. First, it is emphasized that the competition on the merits is permissible and desirable. The competition forces less efficient and weaker competitors to leave the market. As the CJEU correctly pointed out, not every exclusionary effect of a price policy is necessarily detrimental to competition on the market. The selective function of competition on the relevant market has positive consequences and can increase pressure on undertakings to compete more vigorously. Art. 102 TFEU is only concerned with the exclusion of rivals that are as efficient as the dominant firm (Ibanez Colomo, 2018b: 2). Second, only practices capable of having foreclosure effects are prohibited by Art. 102 TFEU. The CJEU made clear that a dominant undertaking can contend the anticompetitive effects of exclusivity rebates and in that case, the Commission has to carry out the test that requires a »balancing of the favourable and unfavourable effects of the practice in question on competition $« .{ }^{90}$ There is no single or bright-line test to be applied to all rebates cases. Rather, their lawfulness should be assessed in each individual case.

The CJEU Judgment has shown that incremental refinement of the principles set out in Hoffmann-La Roche is under way (see Colomo, 2018a: 197) and that the CJEU is ready to move away from traditional jurisprudence. However, it cannot be asserted

\footnotetext{
${ }^{88}$ Opinion Of Advocate General Wahl in case C-413/14 P, Intel v Commission, ECLI:EU:C:2016:788, para. 115.

${ }^{89}$ Ibid., para. 117.

${ }^{90}$ Case C-413/14 P, Intel v Commission, ECLI:EU:C:2017:632, para. 140.
} 
that the more formalistic approach has been definitely relinquished. The CJEU Judgment suggests that the approach of the courts to rebate policies of dominant undertakings will change, since it will not be tenable to rely simply on form-based infringement findings. Although indications of an effects-based approach were visible in Post Danmark I, now the doctrine of effects is more prominent.

The CJEU Judgment is in line with the Commission«s approach underlined in the Guidance on Article 102 TFEU. It is the first time that the CJEU has required an effects-based analysis in an exclusivity rebate case. Namely, the burden on the Commission to analyse all the relevant circumstances arises in the case where a dominant firm submits evidence to support the contention that its conduct could not actually have distorted competition. The CJEU Judgment shows that an economic analysis will become much more important not only in future rebates cases, but by analogy also in other abuse of dominance cases.

\section{References}

Ezrachi, A. (2016) EU Competition Law - An Analitical Guide to the Leading Cases, (Oxford: Hart Publishing).

Faull, J., Nikpay, A. (2014) The EU Law of Competition (Oxford: Oxford University Press).

Fox, E.M., Gerard, D. (2017) EU Competition Law - Cases, Texts and Context (Cheltenham: Edward Elgar).

Giles, I., Modrall, J. (2017) Major victory for Intel as CJEU sends case back to General Court for re-examination (Kluwer Competition Law Blog) available at http://competitionlawblog.kluwercompetitionlaw.com/2017/09/12/major-victoryintel-cjeu-sends-case-back-general-court-re-examination/ (accessed 10 November 2018).

Ibanez Colomo, P. (2014) Intel and Article 102 TFEU Case Law: Making Sense of a Perpetual Controversy, LSE Law, Society and Economy Working Papers 29/2014, pp. $1-32$.

Ibanez Colomo, P. (2018a) The Shaping of EU Competition Law (Cambridge: Cambridge University Press).

Ibanez Colomo, P. (2018b). The Future of Article 102 TFEU after Intel, SSRN Electronic Journal, pp. 1-26, doi:10.2139/ssrn.3125468.

Jones, A., Sufrin, B. (2016) EC Competition Law - Text, Cases and Materials (Oxford: Oxford University Press).

Petit, N. (2018) The Judgment of the EU Court of Justice in Intel and the Rule of Reason in Abuse of Dominance Cases available at https://papers.ssrn.com/sol3/papers.cfm? abstract_id $=3086402$.

Whish, R. (2015) Intel v Commission: Keep Calm and Carry on!, Journal of European Competition Law \& Practice, 6(1), pp. 1-2.

Whish, R., Bailey, D. (2015) Competition Law (Oxford: Oxford University Press).

Cleary Gottlieb Steen \& Hamiliton LLP (2017) Modernising Abuse of Dominance - the CJEU«s Intel Judgement available at https://www.clearygottlieb.com/ /media/organizearchive/cgsh/files/2017/publications/alert-memos/modernising-abuse-of-dominancethe-cjeus-intel-judgment-10-17-17.pdf. 